\title{
BUILDING LITERACY CULTURE THROUGH PARENT INVOLVEMENT ON EARLY AGED CHILDREN IN SUKARAPIH VILLAGE, TAMBELANG, BEKASI, WEST JAVA
}

\author{
Lidia HANDAYANI*, Evelyne HANASETA, and Ibnu FAZHAR \\ Sahid University, Indonesia \\ *lidyahandayani008@gmail.com
}

\begin{abstract}
To build Children habit on read to more frequently at an early age required several efforts. Study has been conducted in Sukarapih Village, Bekasi, West Java, Indonesia to examines the effect of parental involvement on children early aged and the effect of child's own reading and other cognitive skill. Current condition in Sukarapih Village is children's literacy skill was still low. Some factors effected this condition are (a) Parents did not encourage their child to reading more books therefore child more interest on gadgets or watching television (b) lack of facilities and infrastructure for early age children to explore book from an early age. Furthermore, Pre school and kindergarden is not available in that village. The approach carried out by activities as follow (1)Educated parents how importance of reading from early aged (2)Provide reading book corners so that book access easier for children in village. Evaluation activities conducted and give result children has their own as reading with a maximum frequency 3 books per month, drawing or book coloring with maximum frequency 1-2 times per month, and Learning to Write with maximum frequency activities 4 times per month
\end{abstract}

Keywords: Children, Reading, Parent, Book, Learning

\section{BACKGROUND}

Less interest on reading from early aged recently become concern issue. Reading interest and awareness is part indicator of nation's quality. Researchs explained that reading behavior should be build from early age so children would be more interest in reading. Reading culture would be hard to implemented when children has grow up. Some causes of less interest in reading from early aged children are the difficulty of accessing books due to the limitations of the school library, increasing access to television and increasing usage of mobile phones and internet access.

To build Children habit on read to more frequently at an early age required several efforts. Previous studies have found a positive association of parents reading to their children and the child's subsequent reading skills, language skills and cognitive development. In other hand children access to book has to be facilitated by children reading park.

Study has been conducted in Sukarapih Village, Tambelang District, Bekasi, West Java, Indonesia. Sukarapih village has $4,2 \mathrm{~km} 2$ area with population amount as 7,622 people consist of 3,761 men and 3,861 women (BPS, Tambelang District). Sukarapih village situated in the northeast Jakarta with distance about $68,1 \mathrm{~km}$ from Jakarta. Location Map of Sukarapih village explained in Figure 1.

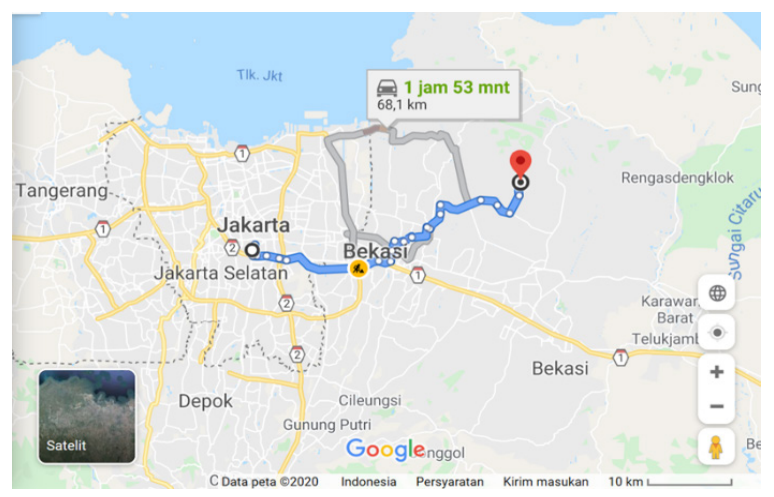

Figure 1 Map Location of Sukarapih Village
Sukarapih Village geographic location bordered by - Northern Point : Sukarahayu Village

- Southern Point : Sukaraja Village

- Western Point : Sukamaju Village

- Eastern Point : Sukatani Village

Number of school in Tambelang District based on Data 2008 could be seen in the Table 1 .

Table 1. School Number in Tambelang District

\begin{tabular}{lcccc}
\hline & $\begin{array}{c}\text { Kinder } \\
\text { Garden }\end{array}$ & $\begin{array}{c}\text { Elementary } \\
\text { School }\end{array}$ & $\begin{array}{c}\text { Junior High } \\
\text { School }\end{array}$ & $\begin{array}{c}\text { Senior } \\
\text { High } \\
\text { School }\end{array}$ \\
\hline Sukamaju & - & 3 & - & - \\
Sukaraja & - & 2 & 1 & - \\
Sukarapih & - & 3 & 2 & 1 \\
Sukarahayu & - & 2 & 1 & - \\
Sukabakti & - & 1 & - & - \\
Sukawijaya & - & - & - & - \\
Sukamantri & - & - & - & - \\
\hline
\end{tabular}

Based on Table 1, can be seen that quantity number of school in Sukarapih village more complete than other village in Tambelang District so this village has potential area for implementation of reading park corner. In addition, in Sukarapih Village there is no kindergarden so that reading park could become a learning center for early aged children.

And to examines the effect of parental reading to children early in life on the child's own reading and other cognitive skill. Current condition in Sukarapih Village is children's literacy skill was still low. Some factors effected this condition are (a) Parents did not encourage their child to reading more books therefore child more interest on gadgets or watching television (b) lack of facilities and infrastructure for early age children to explore book from an early age. Furthermore, Pre school and kindergarden is not available in that village.

The study focuses on parents' reading to children at 4 years of age and the subsequent development of very early 
reading skills (at age 4-5). This focus on early reading skills is relevant since early remedial or stimulating activities may be important for later reading skills/proficiency. Approch conducted through (a)socialization training and counseling for parents regarding importance of reading book and (b) provide facilities of book corner.

\section{METHOD}

The approach in the literacy method in Sukarapih Village is carried out by providing theory and practical examples as well as fostering motivation to increase the enthusiasm of parents in assisting children to grow. The approach to the activity is conveyed by adjusting the training participants who are a pair of parents and children. The conditions of the trainees are as follows:

- Parents' education at the elementary, middle, and high school levels. So that the adjustment of the material is done in terms that are easy to understand

- Perception and Knowledge Parents who think that literacy is difficult to apply and the benefits of literacy will not change the current economic condition

- Limited sources of books hinder the literacy process in society so that parents give up.

The activity approach is carried out by preparing material using easy vocabulary and providing real examples of the benefits of literacy for education and knowledge without the limitations of socio-economic conditions. Some activities conducted as follow

1. Educated parents in Sukarapih Village how importance of reading from early aged. Parent approach considerated family education background includes a wide range of information relating to the child's family environment, early childhood and schooling experiences, and physical, socio-emotional and learning outcomes.

2. Provide reading book corners so that book access easier for children in village. Limited book access in Village become an issue that influenced parents effort to build reading interest on early aged children

This study considered the influence of the frequency of reading to children at age 4-5 in terms of their current and future performance on measures relating to (a)Reading Books,(b)Book Coloring, (c)Writing.

The stages of the activities carried out are 1-day training to describe the existing problems, as well as several problem-solving methods that are applied through the following stages of the Community Partnership Program activities that will be carried out:

\section{RESULTS AND DISCUSSION}

The activities carried out during 1 day trining to brainstorming existing problem and discussion methods to solve some problem that faced by parent to encourage child to love reading

\begin{tabular}{|c|c|c|c|}
\hline Day/Date & Time & Activities & $\begin{array}{c}\text { Achievement } \\
\text { Target }\end{array}$ \\
\hline $\begin{array}{l}\text { Monday /13 } \\
\text { April } 2021\end{array}$ & $\begin{array}{l}10 \mathrm{am} \\
-11 \mathrm{am}\end{array}$ & $\begin{array}{l}\text { Counseling to } \\
\text { parents about the } \\
\text { importance of } \\
\text { reading books in } \\
\text { children from an } \\
\text { early age. }\end{array}$ & $\begin{array}{l}\text { Parent encourage } \\
\text { child to love } \\
\text { reading while free } \\
\text { time }\end{array}$ \\
\hline $\begin{array}{l}\text { Monday /13 } \\
\text { April } 2021\end{array}$ & $\begin{array}{l}10 \mathrm{am} \\
-12 \mathrm{am}\end{array}$ & $\begin{array}{l}\text { Reading Park } \\
\text { Corner in } \\
\text { Sukarapih } \\
\text { Village }\end{array}$ & $\begin{array}{l}\text { Existing of } \\
\text { Reading Park } \\
\text { Corner }\end{array}$ \\
\hline \multirow[t]{2}{*}{$\begin{array}{l}\text { Senin/13 April } \\
2021\end{array}$} & $\begin{array}{l}\text { 11.am- } \\
\text { 12.am }\end{array}$ & $\begin{array}{l}\text { Story telling } \\
\text { for play group } \\
\text { children and } \\
\text { reading book } \\
\text { activity for } \\
\text { elementary student }\end{array}$ & $\begin{array}{l}\text { Building child } \\
\text { interest in reading }\end{array}$ \\
\hline & $\begin{array}{l}\text { 12.am- } \\
\text { 13.am }\end{array}$ & $\begin{array}{l}\text { Exercise story } \\
\text { synopsis }\end{array}$ & $\begin{array}{l}\text { Children could } \\
\text { understand what } \\
\text { they read and } \\
\text { conclude it to the } \\
\text { form of a synopsis } \\
\text { and Q\&A }\end{array}$ \\
\hline
\end{tabular}

First approach conducted through parent education $\&$ counseling. The counseling is divided into three main parts, (1)Training \& counseling of understanding and methods to build literacy (2) Group discussion about children's interests and what potential can be developed at home. (3) application of the literacy method which is carried out through the methods of storytelling, drawing, and coloring.

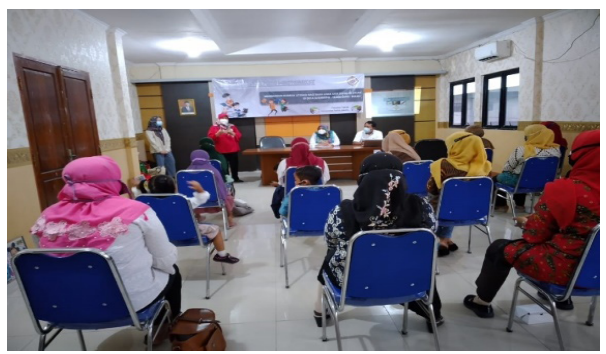

Figure 2 Training \& counseling to parents in Sukarapih Village

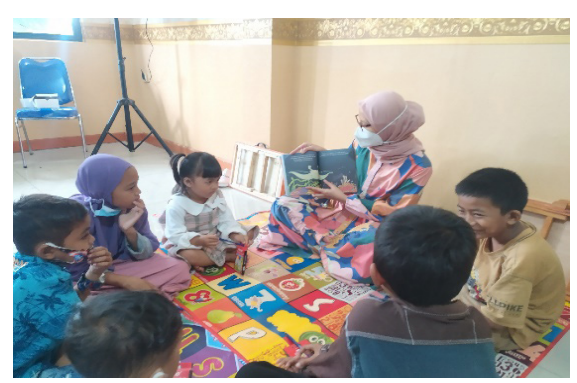

Figure 3 Storytelling to Children in Sukarapih Village

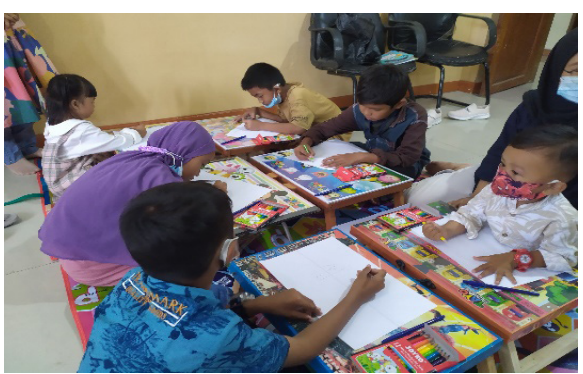

Figure 4 Children coloring activities in Sukarapih Village 
The practice of literacy activities was carried out in picture 2 and picture 3 this practice was carried out as an example of applying literacy at home. In the practice of literacy by storytelling, children's knowledge will increase according to the selected storybook theme. The storytelling activity was chosen using an animal theme to attracted children interest in general, then the children's focus were evaluated by asking questions about the story at the end of the session. The third session was carried out by giving children sheets to draw and freeing children to draw according to their wishes, this method was chosen to develop children's creations, then children were asked to write short stories about the pictures they made or tell the contents of the pictures.

Evaluation of this activites conducted through parents online report. Evaluation of literacy activities is carried out during 1 month. The role of parents in assisting children on literacy activities report through Whatsapp group.

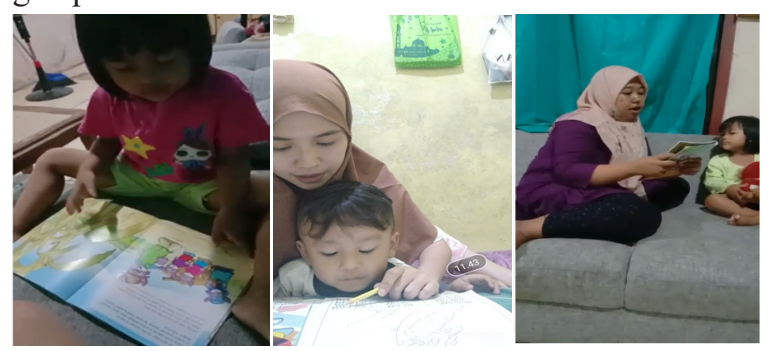

Figure 5. Parents involvement on children literacy activities

Based on monitoring activities, result of literacy activities that has been conducted give impact to children activies at home as follow:

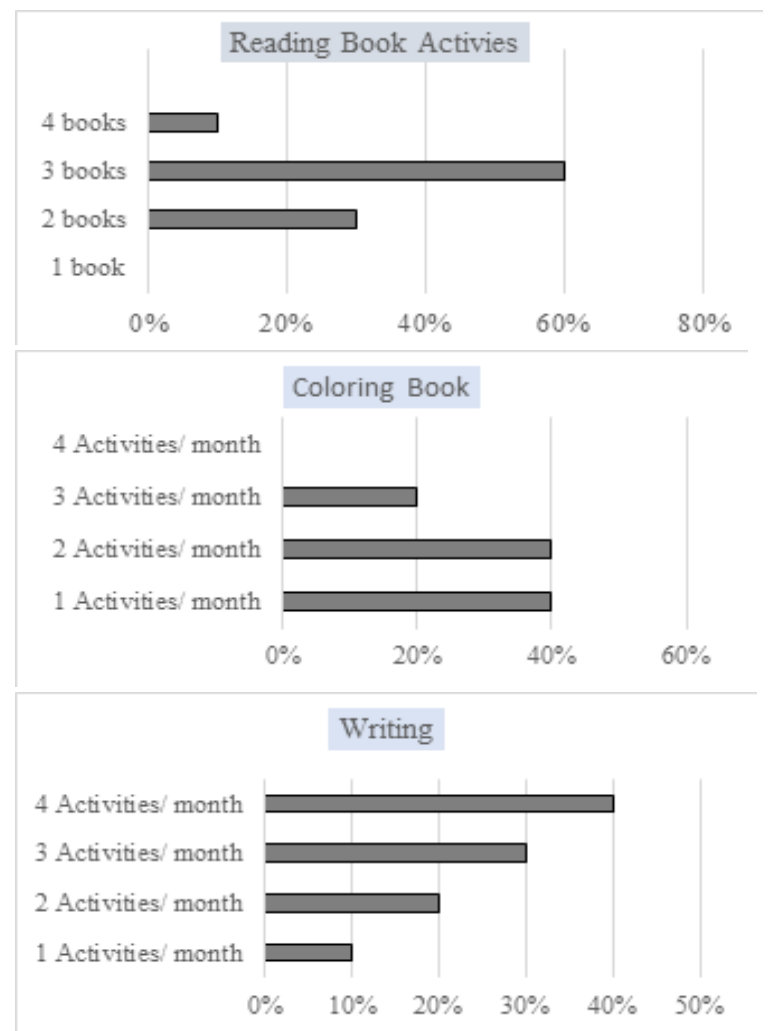

Monitoring activities conducted on parents who participated on education \& counseling literacy with percentage of parents participation is $100 \%$. The child who has achieved highest number of activities giving reward.

\section{CONCLUSION}

Counseling on literacy methods was delivered to parents, meanwhile children were given materials story telling. In other hand to supporting literacy activities, a reading corner was established in Sukarapih Village sub-district and evaluation was carried out through online reports. Literacy activities are evaluated based on several types of activities such as Reading with a maximum frequency 3 books per month, Drawing or Book Coloring with maximum frequency 1-2 times per month, and Learning to Write with maximum frequency activities 4 times per month

\section{REFERENCE}

Badan Pusat Statistik. 2018. Kecamatan Tambelang Dalam Angka. Jakarta : Bps.

Pendit, Putu Laxman. Penelitian Ilmu Perpustakaan Dan Informasi: Sebuah Pengantar Diskusi Epistemologi Dan Metodologi. Jakarta: Jip-Fsui. 2003.

Pendit, Putu Laxman. Apa Yang Selama Ini Dikaji Ilmu Perpustakaan Dan Informasi. Makalah Sebagai Bahan Diskusi Dengan Pengajar Jurusan Ilmu Perpustakaan Dan Informasi Fikom Unpad Bandung. 2009.

Octroaica Cempaka Jene. 2013.Peran Taman Bacaan Masyarakat Dalam Menumbuhkan Budaya Baca Anak Di Taman Bacaan Masyarakat "Mortir" Banyumanik-Semarang. Jurnal Ilmu Perpustakaan. Vol 2, No 2 (2013).

Direktorat Pendidikan Masyarakat. 2009. Taman Bacaan Masyarakat: Pedoman Penyelenggaraan. Direktorat Jenderal Pendidikan Nonformal Dan Informal: Departemen Pendidikan Nasional.

Figure 6. Result of children literacy activity with parents involvement 